\title{
FAKTOR-FAKTOR YANG MEMPENGARUHI MUZAKI \\ MEMBAYAR DAN TIDAK MEMBAYAR ZAKAT \\ PADA LAZISMU KABUPATEN JEMBER
}

\author{
Munadzir Ahsan Al Ghofiqi \\ Universitas Muhammadiyah Jember \\ munadz.pink@gmail.com
}

\begin{abstract}
This research focuses on factors that influence muzaki in whether they pay zakat or not to LAZISMU Jember. It aims to reveal each variable which influences and distunguish it significantly. The variables used are organisation, knowledge and understanding on the applied rules and good zakat governance. The object of this research is muzaki who pay and who do not pay zakat to LAZISMU Jember. The respondents of this research are 60 muzaki and the research was done in a month. The result of data analysis using discriminant analysis reveals that there is significant difference. The significant difference is based on F Test to variable knowledge and understanding on the applied rules and good zakat governance. Both variables influence and distunguish significantly to muzaki in whether they pay zakat or not to LAZISMU Jember. While the organisation variables can't be included in the discriminant model because of that variables are not able to distinguish muzaki pay zakat or not to LAZISMU Jember. Thus, variable organisation does not influence and distingush significantly to muzaki whether they pay zakat or not to LAZISMU Jember.
\end{abstract}

Keywords: Good Zakat Governance, LAZISMU, Muzaki, Organisation.

\section{PENDAHULUAN}

Zakat sangatlah mungkin menjadi alternatif program pemerintah sebagai sumber dana untuk mengatasi kemiskinan (Ibrahim, 2008). Zakat merupakan sarana yang dilegalkan oleh agama Islam dalam pembentukan modal. Pembentukan modal tidak semata-mata dari pemanfaatan dan pengembangan sumber daya alam, melainkan juga berasal dari sumbangan wajib orang kaya. Zakat juga berperan penting dalam peningkatan kualitas sumber daya manusia dan penyediaan sarana dan prasarana produksi (Miftah, 2008).

Kehadiran lembaga zakat di Indonesia dimulai ketika sebelas ulama menyampaikan pendapatnya kepada Presiden Suharto pada tanggal 24 September 1968, yang ditindaklanjuti dengan seruan Presiden Suharto pada peringatan Isra' Mi'raj di Istana Merdeka pada tanggal 26 Oktober 1968. Sejak saat itu perintisan pendirian lembaga pengelolaan zakat formal, 
khususnya di Ibu Kota Jakarta terus berlangsung. Lembaga formal pertama yang berdiri adalah Badan Amil Zakat, Infak dan Shadaqah (BAZIS) DKI Jakarta (Kuntarno, 2006).

Dibentuknya sebuah Badan Amil Zakat di Indonesia ini ternyata belum menjawab masalah pengentasan kemiskinan. Salah satu dampaknya adalah ketidakpuasan muzakki dalam menggunakan jasa BAZ sebagai sarana dalam menyalurkan kewajiban zakatnya sehingga menimbulkan sebuah alternatif perilaku dalam penyaluran zakat yaitu penyaluran zakat yang dilakukan secara individu dimana muzaki akan mencari mustahik secara individu pula. Jadi, perlu adanya optimalisasi peran dan fungsi dari BAZ.

Nurul (2014) menjelaskan bahwa di Kabupaten Jember terdapat 7 (tujuh) lembaga amil zakat yang masih tetap eksis keberadaannya, yaitu LAZISMU (Lembaga Amil, Zakat, Infak dan Shodaqoh Muhammadiyah), AZKA (Amil Zakat Al-Baitul Amien), Yatim Mandiri, LAZ Kemenag (Lembaga Amil, Zakat Kementerian Agama Jember), YDSF (Yayasan Dana Sosial Alfalah), BMH (Baitul Mal
Hidayatullah) dan RIZKI (Rumah Itqon Zakat).

Jika setiap umat Islam menyadari tentang kewajiban berzakat dan mengetahui berbagai macam manfaat yang akan diperoleh dengan berzakat pada LAZ, maka potensi zakat seharusnya tercapai. Kemudian, lebih penting lagi adalah bahwa dana zakat yang ada pada LAZ tidak hanya terkumpul secara optimal, namun diharapkan terjadi distribusi yang adil diantara penerima zakat, sehingga manfaatnya lebih terasa.

Dalam penelitian ini, peneliti menentukan 3 faktor diantaranya faktor organisasi, faktor pengetahuan dan pemahaman tentang peraturan yang berlaku dan faktor good zakat governance (tata kelola zakat yang baik). Penentuan faktor tersebut didasari oleh hasil wawancara yang telah dilakukan dan menghasilkan kesimpulan bahwa LAZISMU Kabupaten Jember membutuhkan perbaikan secara terus menerus di organisasinya, kemudian memberikan pengetahuan dan pemahaman tentang peraturan zakat yang berlaku serta menjalankan manajemen pengelolaan zakat, dalam hal ini sistem pengendalian intern yang 
efektif, dimana dapat berperan dalam terwujudnya good zakat governance (tata kelola zakat yang baik). Beberapa hal tersebut harus tersampaikan kepada muzaki melalui berbagai media bahwa LAZISMU Kabupaten Jember berusaha untuk terus meningkatkan kualitasnya.

Sebagai ilustrasi awal penulis menduga bahwa faktor organisasi, pengetahuan dan pemahaman tentang peraturan yang berlaku dan good zakat governance sebagai faktor yang berpengaruh dan membedakan secara signifikan terhadap muzaki membayar dan tidak membayar zakat pada LAZISMU Kabupaten Jember.

Berangkat dari hal tersebut, maka penulis akan melakukan penelitian mengenai Faktor-Faktor Yang Mempengaruhi Muzaki Membayar dan Tidak Membayar Zakat pada Lazismu Kabupaten Jember. Dalam penelitian ini, penulis akan mencari berbagai alasan yang mendasari seseorang untuk membayar zakat pada lembaga amil zakat.

\section{TINJAUAN PUSTAKA}

\subsection{Landasan Teori}

Menurut bahasa (etimologi), zakat berasal dari kata dasar zaka yang berarti tumbuh, berkah, bersih dan berkembang, sedangkan pengertian zakat menurut terminologi adalah sejumlah harta tertentu yang diwajibkan oleh Allah SWT untuk diberikan kepada orang yang berhak menerima zakat (mustahik) dengan syarat-syarat tertentu (Kurnia dan Hidayat, 2008).

Ditinjau dari sistem ekonomi Islam, zakat sebagai salah satu instrumen fiskal untuk mencapai tujuan keadilan sosial dan keadilan ekonomi serta distribusi kekayaan dan pendapatan, secara aklamasi dipandang sebagai bagian tak terpisahkan dari falsafah moral Islam dan didasarkan pada komitmen yang pasti terhadap persaudaraan kemanusiaan (Qardhawi dalam Asnaini, 2008 : 92). Perwujudan menegakkan keadilan yang terpenting dan berpengaruh ialah menegakkan keadilan dibidang ekonomi atau pembagian kekayaan diantara anggota masyarakat. Keadilan menuntut agar setiap orang dapat bagian yang wajar dari kekayaan atau rezeki (Nur Cholis dalam NDP Hasil-Hasil Kongres HMI XVIII, 2013). 


\subsection{Variabel Penelitian}

\section{Organisasi}

Hasil penelitian yang dilakukan oleh Ahmad, Wahid dan Mohamad (2005) menyebutkan bahwa faktor utama yang mempengaruhi individu dalam membayar zakat kepada lembaga formal adalah disebabkan kepuasan tentang distribusi yang dilakukan oleh organisasi zakat dan kecakapan kerja pengurus zakat itu sendiri. Hal ini diperkuat oleh penelitian yang dilakukan oleh Muda et al. (2006). Dalam penelitian mereka disebutkan bahwa organisasi pengelola zakat memiliki peran yang penting dalam memotivasi seseorang untuk berzakat. Pada tahun-tahun sebelumnya didapatkan bahwa peningkatan penyerapan zakat yang signifikan terjadi karena upaya dari organisasi zakat.

Faktor organisasi menilai kemampuan organisasi dalam menyerap zakat dari masyarakat. Indikator yang termasuk dalam faktor ini diantaranya adalah tingkat kecakapan organisasi zakat dalam mengumpulkan dana zakat dan menyalurkannya kembali dan organisasi zakat yang transparan dalam administrasi (Mukhlis, 2011).

\section{Pengetahuan dan Pemahaman} Tentang Peraturan yang Berlaku

Pengetahuan tentang peraturan zakat yang dimiliki, jika terarah dengan baik akan lebih mendorong dan memotivasi muzaki dengan segera untuk mengeluarkan zakat atau membayar zakat harta yang mereka miliki suatu kewajiban yang harus ditunaikan dengan segera (Lusiana, 2010).

Endah (2006) menyebutkan bahwa faktor pemahaman muzaki terhadap peraturan zakat berpengaruh positif terhadap jumlah zakat terkumpul.

\section{Good Zakat Governance}

Menurut Andi (2011), Good Zakat Governance meliputi akuntabilitas, transparansi, profesionalisme, daya tanggap, keadilan, berorientasi pada kemaslahatan umat, efektif dan efisien serta berada dalam kerangka hukum syariah.

\subsection{Pengembangan Hipotesis}

Dari variabel diatas memberikan penjelasan bahwa Faktor Organisasi, Pengetahuan dan Pemahaman Tentang Peraturan yang Berlaku dan Good Zakat Governance secara signifikan mempengaruhi muzaki membayar dan tidak membayar zakat pada LAZISMU 
Kabupaten Jember, maka pengembangan hipotesis adalah sebagai berikut:

1. Pengaruh Faktor Organisasi terhadap Muzaki Membayar dan Tidak Membayar Zakat Pada LAZISMU Kabupaten Jember

$H_{1}$ : Organisasi $\left(\mathrm{X}_{1}\right)$ berpengaruh dan membedakan secara signifikan terhadap Muzaki Membayar dan Tidak Membayar Zakat Pada LAZISMU Kabupaten Jember (Y).

2. Pengaruh Faktor Pengetahuan dan Pemahaman tentang Peraturan yang Berlaku terhadap Muzaki Membayar dan Tidak Membayar Zakat Pada LAZISMU Kabupaten Jember

$\mathrm{H}_{2}$ : Pengetahuan dan Pemahaman Tentang Peraturan yang Berlaku $\left(\mathbf{X}_{2}\right)$ berpengaruh dan membedakan secara signifikan terhadap Muzaki Membayar dan Tidak Membayar Zakat Pada LAZISMU Kabupaten Jember (Y).

3. Pengaruh Faktor Good Zakat Governance terhadap Muzaki Membayar dan Tidak Membayar Zakat Pada LAZISMU Kabupaten Jember

$\mathrm{H}_{3}$ : Good Zakat Governance $\left(\mathrm{X}_{3}\right)$ berpengaruh dan membedakan secara signifikan terhadap Muzaki

Membayar dan Tidak Membayar

Zakat Pada LAZISMU Kabupaten

Jember (Y).

\section{METODE PENELITIAN}

\subsection{Jenis Penelitian}

Penelitian yang dilakukan adalah penelitian kausal (mempengaruhi). Penelitian ini mencoba untuk menjelaskan pengaruh Organisasi, Pengetahuan dan Pemahaman tentang Peraturan yang Berlaku dan Good Zakat Governance terhadap Muzaki Membayar dan Tidak Membayar Zakat Pada LAZISMU Kabupaten Jember. Pada penelitian ini terdapat pengujian hipotesis serta melakukan analisis dari data yang diperoleh. Penjelasan yang dilakukan pada penelitian ini adalah menjelaskan pengaruh Organisasi, Pengetahuan dan Pemahaman tentang Peraturan yang Berlaku dan Good Zakat Governance terhadap Muzaki Membayar dan Tidak Membayar Zakat Pada LAZISMU Kabupaten Jember.

\subsection{Jenis dan Sumber Data}

Data yang digunakan dalam penelitian ini terbagi atas dua jenis, yakni data primer dan data sekunder. 


\subsection{Teknik Pengumpulan Data}

Pengumpulan data dalarn penelitian ini dilakukan dengan cara wawancara dan kuesioner (angket).

\subsection{Populasi dan Sampel}

Populasi pada penelitian ini adalah para muzaki yang membayar dan tidak membayar zakat pada LAZISMU Kabupaten Jember. Jumlah populasi yang ada pada LAZISMU Kabupaten Jember ini tidak tersusun jumlahnya dikarenakan tidak menentunya muzaki yang membayar zakat di LAZISMU Kabupaten Jember. Sehingga dilakukan pengambilan sampel guna efisiensi waktu dan biaya.

Hair et al.(1998) menyatakan bahwa jumlah sampel minimal yang harus diambil apabila menggunakan teknik analisis regresi berganda adalah 15 sampai 20 kali jumlah variabel yang digunakan. Jumlah variabel yang digunakan dalam penelitian ini adalah 4 variabel sehingga jumlah sampel yang harus diambil adalah 4 x $15=60$.

Jumlah sampel yang ideal dalam analisis diskriminan secara pasti tidak ada. Pedoman yang bersifat umum menyatakan untuk setiap variabel independen sebaiknya ada 5-20 (sampel). Dengan demikian, jika ada 8 variabel independen, seharusnya minimal $8 \times 5=40$ sampel. Secara terminologi SPSS, jika ada 8 kolom variabel independen, sebaiknya ada 40 baris data (Santoso, 2002 : 144). Sedangkan pada penelitian ini terdapat 3 variabel independen, maka ditentukan 3 x $20=60$ sampel. Jadi, 30 sampel adalah muzaki yang membayar zakat pada LAZISMU Kabupaten Jember dan 30 sampel lainnya adalah muzaki yang tidak membayar zakat pada LAZISMU Kabupaten Jember. Jumlah sampel ini sudah sesuai dengan jumlah sampel minimal yang harus diambil berdasarkan syarat yang ditetapkan ole Hair et al. (1998).

\subsection{Identifikasi Variabel dan Definisi Operasional Variabel}

\subsubsection{Identifikasi Variabel}

Variabel dalam penelitian ini diantaranya variabel independen (bebas) dan variabel dependen (terikat).Variabel independen $(\mathrm{X})$ atau variabel bebas dalam penelitian ini adalah Faktor Organisasi $\left(\mathrm{X}_{1}\right)$, Faktor Pengetahuan dan Pemahaman tentang Peraturan yang Berlaku $\left(\mathrm{X}_{2}\right)$ dan Faktor Good Zakat Governance $\left(\mathrm{X}_{3}\right)$. Adapun variabel 
dependen (Y) atau variabel terikat dalam penelitian ini adalah kategori muzaki, membayar dan tidak membayar.

\subsubsection{Definisi Operasional Variabel}

\section{Faktor Organisasi}

Peneliti menentukan indikator pada faktor organisasi $\left(\mathrm{X}_{1}\right)$ ini yakni tingkat kecakapan organisasi mengumpulkan dana zakat, tingkat kecakapan organisasi menyalurkan dana zakat, kepercayaan kepada institusi, kemudahan mekanisme pembayaran, kepuasan terhadap institusi, kemudahan prasarana. Variabel ini diukur dengan skala Likert 5 poin untuk 6 pertanyaan.

2. Faktor Pengetahuan dan Pemahaman Tentang Peraturan yang Berlaku Peneliti menentukan indikator pada faktor pengetahuan dan pemahaman tentang peraturan yang berlaku $\left(\mathrm{X}_{2}\right)$ ini yakni pengetahuan muzaki tentang peraturan zakat, pemahaman muzaki tentang peraturan zakat, pelaksanaan undang-undang zakat yang jelas, pelaksanaan undang-undang zakat yang tegas, fatwa tentang zakat, tanggapan individu terhadap undang-undang zakat. Variabel ini diukur dengan skala Likert 5 poin untuk 6 pertanyaan.

\section{Faktor Good Zakat Governance}

Peneliti menentukan indikator pada faktor organisasi $\left(\mathrm{X}_{1}\right)$ ini yakni akuntabilitas, transparansi, profesionalisme, daya tanggap, keadilan, berorientasi pada kemaslahatan umat, efektif dan efisien serta berada dalam kerangka hukum syariah. Variabel ini diukur dengan skala Likert 5 poin untuk 8 pertanyaan.

\subsection{Teknik Analisis Data}

Teknik analisis data dalam penelitian ini menggunakan analisis diskriminan yang termasuk dalam multivariate dependence method, dengan model:

$$
Y=X_{1}+X_{2}+\ldots+X_{n}
$$

Keterangan:

1. Variabel independen $\left(\mathrm{X}_{1}\right.$ dan seterusnya) adalah data metrik, yakni data berjenis interval atau rasio.

2. Variabel dependen(Y) adalah data kategorikal atau nominal, seperti golongan membayar (kode 1), golongan tidak membayar (kode 2) dan sebagainya. Jika data kategorikal tersebut hanya terdiri atas dua kode 
saja, maka model bisa disebut

Two-Group Discriminant Analysis.

Sedangkan jika kode lebih dari dua kategori, disebut dengan Multiple Discriminant Analysis.

\section{HASIL DAN PEMBAHASAN}

\subsection{Gambaran Umum Objek Penelitian}

Lembaga Amil Zakat, Infaq dan Sedekah Muhammadiyah (LAZISMU) adalah lembaga zakat tingkat nasional yang berkhidmat dalam pemberdayaan masyarakat melalui pendayaagunaan secara produktif dana zakat, infaq, wakaf dan dana kedermawanan lainnya baik dari perseorangan, lembaga, perusahaan dan instansi lainnya. Didirikan oleh PP. Muhammadiyah pada tahun 2002 yang ditandai dengan penandatanganan deklarasi oleh Prof. Dr. HA. Syafi'i Ma'arif, MA (Buya Syafi'i) dan selanjutnya dikukuhkan oleh Menteri Agama Republik Indonesia sebagai Lembaga Amil Zakat Nasional melalui SK No. 457/21 November 2002.

LAZISMU Kabupaten Jember merupakan bagian dari Lembaga Amil Zakat (LAZ) Nasional dibawah LAZISMU Nasional. Bertempat di Jl. Bondoyudo No. 11 Jember.

\subsection{Hasil Analisis Data}

\subsubsection{Pengujian Instrumen Penelitian}

1. Uji Validitas

Semua variabel memiliki nilai signifikansi $\mathrm{r}$ hitung dibawah 0,05. Dengan demikian dapat diambil kesimpulan bahwa setiap item pertanyaan dalam kuisioner dikatakan valid, yang artinya variabel tersebut mampu mengukur aspek yang sama atau apa yang ingin diukur.

2. Uji Realibilitas

Semua variabel yang digunakan dalam penelitian ini adalah reliabel, karena memiliki nilai Cronbach Alpha $(\alpha)$ lebih besar dari 0,60. Sesuai yang disyaratkan oleh Ghozali (2005:42) bahwa suatu konstruk dikatakan reliabel jika nilai Cronbach Alpha lebih dari 0,60.

\subsubsection{Analisis Deskriptif}

Diketahui penilaian variabel organisasi $\left(\mathrm{X}_{1}\right)$ pada kelompok muzaki membayar zakat dan tidak membayar zakat. Pada kelompok muzaki membayar zakat sebagian besar memberikan jawaban setuju yang berarti responden mempersepsikan aspek-aspek organisasi pada LAZISMU Kabupaten 
Jember sudah baik. Pada kelompok muzaki tidak membayar zakat sebagian besar juga memberikan jawaban setuju yang berarti responden mempersepsikan aspek-aspek organisasi pada LAZISMU Kabupaten Jember sudah baik.

Diketahui penilaian variabel Pengetahuan dan Pemahaman tentang Peraturan yang Berlaku $\left(\mathrm{X}_{2}\right)$ pada kelompok muzaki membayar zakat dan tidak membayar zakat. Pada kelompok muzaki membayar zakat sebagian besar memberikan jawaban setuju yang berarti responden mempersepsikan aspek-aspek Pengetahuan dan Pemahaman tentang Peraturan yang Berlaku pada LAZISMU Kabupaten Jember sudah baik. Pada kelompok muzaki tidak membayar zakat sebagian besar memberikan jawaban netral yang berarti responden mempersepsikan aspek-aspek Pengetahuan dan Pemahaman tentang Peraturan yang Berlaku pada LAZISMU Kabupaten Jember cukup baik.

Diketahui penilaian variabel Good Zakat Governance $\left(\mathrm{X}_{3}\right)$ pada kelompok muzaki membayar zakat dan tidak membayar zakat. Pada kelompok muzaki membayar zakat sebagian besar memberikan jawaban setuju yang berarti responden mempersepsikan aspek-aspek
Good Zakat Governance pada LAZISMU Kabupaten Jember sudah baik. Pada kelompok muzaki tidak membayar zakat sebagian besar memberikan jawaban netral yang berarti responden mempersepsikan aspek-aspek Good Zakat Governance pada LAZISMU Kabupaten Jember cukup baik.

\subsubsection{Analisis Diskriminan}

Standard Canonical Discriminant Function Coefficient menampakkan standard koefisien diskriminannya adalah:

$$
\mathrm{Z}=\mathbf{0 , 6 7 8} \times 2+0,659 \times 3
$$

$\mathrm{Z}=$ Muzaki terdiri dari 2 kelompok yaitu muzaki membayar zakat dan tidak membayar zakat

Diketahui variabel organisasi (X1) tidak dapat dimasukkan kedalam fungsi diskriminan. Variabel organisasi tidak memenuhi syarat masuk ke dalam model diskriminan karena tidak dapat membedakan atau membandingkan muzaki membayar zakat dan tidak membayar zakat. Hal ini mengindikasikan variabel organisasi kurang mempengaruhi muzaki untuk membayar zakat atau tidak membayar zakat. 


\subsubsection{Uji Signifikansi Koefisien} Diskriminan

\section{Uji Signifikansi}

Dengan menggunakan Uji $\mathrm{F}$ dapat diketahui bahwa variabel yang memiliki perbedaan yang signifikan secara statistik adalah variabel Pengetahuan dan Pemahaman Tentang Peraturan yang Berlaku dan Good Zakat Governance. Kedua variabel tersebut memiliki nilai signifikansi Uji F adalah 0,000. Nilai tersebut lebih kecil dari 0,05 sebagai standar penerimaan hipotesis sehingga dapat disimpulkan bahwa kelompok muzaki membayar zakat dengan kelompok muzaki tidak membayar zakat memiliki penilaian yang berbeda secara signifikan terhadap kedua variabel tersebut.

Dapat diketahui pula bahwa nilai Wilk's Lambda konsisten dengan nilai Uji F. Sehingga dapat disimpulkan bahwa variabel Pengetahuan dan Pemahaman Tentang Peraturan yang Berlaku dan Good Zakat Governance dengan nilai Wilk's Lambda masing-masing sebesar 0,715 dan 0,589 menujukkan adanya perbedaan yang signifikan mengenai kedua variabel tersebut yang membuat muzaki membayar zakat atau tidak membayar zakat.

Angka Canonical Corellation adalah sebesar 0,641. Angka tersebut menunjukkan keeratan yang cukup tinggi dengan ukuran skala asosiasi antara 0 sampai 1. Jika nilai Canonical Corellation dikuadratkan atau disebut SquareCanonical Corellation $\left(\mathrm{CR}^{2}\right)$ akan diperoleh nilai sebesar 0,411. Hal ini dapat diartikan bahwa $41,1 \%$ variasi antara kelompok muzaki membayar zakat dan kelompok muzaki tidak membayar zakat dapat dijelaskan oleh variabel diskriminan Pengetahuan dan Pemahaman Tentang Peraturan yang Berlaku dan Good Zakat Governance.

Angka Chi-Square adalah 30,176 dengan nilai signifikansinya adalah 0,000. Hal ini menunjukkan adanya perbedaan faktor Pengetahuan dan Pemahaman Tentang Peraturan yang Berlaku dan Good Zakat Governance yang signifikan (nyata) antara kedua kelompok responden baik kelompok responden yang termasuk muzaki membayar zakat maupun kelompok responden yang termasuk muzaki 
tidak membayar zakat dalam model diskriminan.

2. Tabel Struktur Matriks

Dapat diketahui bahwa variabel Pengetahuan dan Pemahaman Tentang Peraturan yang Berlaku adalah variabel yang paling membedakan muzaki untuk membayar zakat atau tidak membayar zakat pada LAZISMU Kabupaten Jember. Variabel pembeda berikutnya adalah variabel Good Zakat Governance. Namun variabel organisasi tidak dapat dimasukan dalam model diskriminan karena variabel tersebut tidak mampu membedakan muzaki membayar zakat dan tidak membayar zakat. Dengan demikian berdasarkan penelitian ini, pihak LAZISMU Kabupaten Jember harus memperhatikan variabel Pengetahuan dan Pemahaman Tentang Peraturan yang Berlaku dan Good Zakat Governance yang memiliki besaran tertinggi. Hal ini disebabkan kedua variabel tersebut sangat sensitif dalam mempengaruhi muzaki untuk membayar zakat atau tidak membayar zakat.
3. Interpretasi Model Diskriminan

Variabel yang masuk ke dalam model diskriminan di atas adalah variabel Pengetahuan dan Pemahaman Tentang Peraturan yang Berlaku dan Good Zakat Governance. Kedua variabel tersebut masuk ke dalam kelompok muzaki membayar zakat maupun muzaki tidak membayar zakat.

Nilai skor rata-rata pada group statistic yang menyatakan bahwa skor rata-rata muzaki membayar zakat lebih besar daripada nilai skor rata-rata yang dimiliki muzaki tidak membayar zakat. Hal ini mengindikasikan bahwa penilaian muzaki membayar zakat terhadap kedua faktor tersebut (Pengetahuan dan Pemahaman Tentang Peraturan yang Berlaku dan Good Zakat Governance) lebih positif daripada penilaian muzaki tidak membayar zakat.

\subsubsection{Z Cut Off (Perhitungan Angka Kritis)}

Angka kritis merupakan nilai tengah yang membatasi antara kelompok responden yang termasuk muzaki membayar zakat dengan kelompok 
muzaki membayar zakat. Perhitungan angka kritis tersebut adalah sebagai berikut:

$$
\begin{aligned}
& \mathbf{Z}_{c u}=\frac{Z_{A} \boldsymbol{N}_{A}+Z_{B} \boldsymbol{N}_{B}}{\boldsymbol{N}_{A}+\boldsymbol{N}_{\boldsymbol{B}}} \\
& \mathbf{Z}_{c u}= \\
& \frac{[30 x(0,821)]+[30 x(-0,821)]}{30+30} \\
& \mathbf{Z}_{c u}=\mathbf{0 , 0 0 0}
\end{aligned}
$$

Berdasarkan nilai tersebut, jika nilai prediksi kasus di bawah $Z_{\mathrm{cu}}$ $(0,000)$, kasus tersebut dimasukkan pada kelompok tidak membayar zakat dan sebaliknya jika nilai prediksi kasus di atas $\mathrm{Z}_{\mathrm{cu}} \quad(0,000)$, kasus tersebut dimasukkan pada kelompok membayar zakat.

\subsubsection{Uji Ketepatan Klasifikasi}

Setelah diketahui angka kritis adalah 0,000 maka dapat diketahui bahwa nilai skor statistik yang lebih kecil dari 0,000 masuk kelompok responden yang tergolong muzaki tidak membayar zakat (kode 0). Demikian sebaliknya, nilai skor statistik yang lebih besar dari 0,000 masuk ke kelompok responden yang tergolong muzaki membayar zakat (kode 1).

Dilakukan perhitungan dengan menggunakan model diskriminan tampak bahwa dari 30 responden yang termasuk sebagai muzaki tidak membayar zakat, 9 diantaranya masuk dalam kelompok muzaki membayar zakat. Tabel Classification Result pada lampiran 6 menunjukkan bahwa ketepatan prediksi analisis diskriminan pada penelitian ini adalah sebesar $76,7 \%$ dan perhitungan dengan metode Leave One-Cross Validation adalah sebesar $75,0 \%$, sehingga dapat disimpulkan bahwa model diskriminan tersebut memiliki ketepatan tinggi dan memenuhi syarat digunakan sebagai model diskriminan dalam penelitian ini.

\subsection{Pembahasan}

Hasil analisis data dengan menggunakan analisis diskriminan dapat diketahui bahwa terjadi perbedaan yang signifikan faktor-faktor yang mempengaruhi muzaki membayar dan tidak membayar zakat pada LAZISMU Kabupaten Jember. Perbedaan yang signifikan berdasarkan Uji F terjadi pada variabel Pengetahuan dan Pemahaman Tentang Peraturan yang Berlaku dan Good Zakat Governance. 
5. KESIMPULAN, KETERBATASAN DAN SARAN

\subsection{Kesimpulan}

1. Organisasi tidak berpengaruh dan membedakan secara signifikan terhadap muzaki membayar dan tidak membayar zakat pada LAZISMU Kabupaten Jember $\left(\mathrm{H}_{1}\right.$ ditolak).

2. Pengetahuan dan pemahaman tentang peraturan yang berlaku berpengaruh dan membedakan secara signifikan terhadap muzaki membayar dan tidak membayar zakat pada LAZISMU Kabupaten Jember $\left(\mathrm{H}_{2}\right.$ diterima).

3. Good Zakat Governance berpengaruh dan membedakan secara signifikan terhadap kepatuhan muzaki membayar dan tidak membayar zakat pada LAZISMU Jember $\left(\mathrm{H}_{3}\right.$ diterima).

\subsection{Keterbatasan}

1. Penelitian ini hanya menguji tiga variabel yaitu organisasi, pengetahuan dan pemahaman tentang peraturan yang berlaku dan good zakat governance yang mempengaruhi muzaki membayar dan tidak membayar zakat pada LAZISMU Kabupaten Jember.

2. Penelitian ini juga hanya menggunakan responden muzaki yang membayar dan yang tidak membayar di LAZISMU Kabupaten Jember.

\subsection{Saran}

1. LAZISMU Kabupaten Jember sebaiknya lebih mengoptimalkan aspek-aspek yang berkaitan dengan pengetahuan dan pemahaman tentang peraturan yang berlaku serta good zakat governance. Karena kedua variabel tersebut merupakan variabel yang sangat berpengaruh terhadap muzaki membayar dan tidak membayar zakat pada LAZISMU Kabupaten Jember;

2. Hasil penelitian yang menunjukkan nilai SquareCanonical Corellation $\left(\mathrm{CR}^{2}\right)$ sebesar 0,411 yang diartikan bahwa $41,1 \%$ variasi antara kelompok muzaki membayar zakat dan kelompok muzaki tidak membayar zakat dapat dijelaskan oleh variabel diskriminan Pengetahuan dan Pemahaman Tentang Peraturan yang Berlaku dan Good Zakat Governance, sehingga bagi para analis dan akademisi lain dalam penelitian mendatang disarankan untuk menggunakan lembaga amil zakat yang lebih banyak serta penambahan variabel 
lain, misalnya Religious Factors

(Ta'abudi), Self Satisfaction,

Utilitarian Factors, Keimanan,

Penghargaan, Altruisme atau lainnya sehingga nantinya akan diperoleh hasil yang lebih baik.

\section{DAFTAR PUSTAKA}

Ahmad Mukhlis. 2011. Analisis Faktor-Faktor yang Mempengaruhi Tingkat Kepatuhan Membayar Zakat: Studi Kasus Kabupaten Bogor.Skripsi Fakultas Ekonomi dan Manajemen, Institut Pertanian Bogor.

Ahmad, Wahid dan A. Mohamad. 2005. Penswastaan Zakat dan Kesannya Terhadap Pembayaran Secara Formal di Malaysia. Kumpulan Kajian Ekonomi \& Keuangan Islam, Pusat Pengajian Ekonomi, UKM.

Andi Zulfayani. 2011. Studi Evaluatif Atas Sistem Pengendalian Intern Pengelolaan Zakat Pada Lembaga Amil Zakat Nasional Baitul Maal Hidayatullah (BMH) Cabang Makassar. Skripsi, Fakultas Ekonomi dan Bisnis, Universitas Hasanuddin Makassar.

Asnaini. 2008. Zakat Produktif dalam Perspektif Ekonomi Islam. Pustaka Belajar, Bengkulu.

Azhari Akmal Tarigan. 2007. Islam Mazhab HMI, Tafsir Tema Besar Nilai Dasar Perjuangan (NDP). Cet I, GP Press Group, Jakarta.

Endah Tri Winingsih. 2006. Pengaruh Pemahaman Muzaki Terhadap
Jumlah Zakat Terhimpun di Rumah Zakat Indonesia Cabang Yogyakarta. Skripsi, Fakultas Syariah dan Hukum, UIN Sunan Kalijaga Yogyakarta.

Hasil-Hasil Kongres Himpunan Mahasiswa Islam (HMI) XXVIII. 2013. Nilai-Nilai Dasar Perjuangan Nur Cholish Madjid Bab 6. Jakarta.

Hair, dkk. 1998. Multivariate Data Analysis. Fifth Edition. Prentice-Hall International, Inc.

Hikmat Kurnia, Ahmad Hidayat. 2008. Panduan Pintar Zakat. Qultum Media, Jakarta.

Ibrahim. 2008. Pembangunan Ekonomi Melalui Agihan Zakat: Tinjauan Empirikal. Jurnal Syariah, 16 : 223-244.

Kuntarno Noor Aflah. 2006. Zakat dan Peran Negara. Diterbitkan oleh Forum Zakat.

Lusiana Kanji. 2010. Faktor Determinan Motivasi Membayar Zakat. Jurnal Universitas Hasanuddin Makassar.

Miftah. 2008. Pembaharuan Zakat Untuk Pengentasan Kemiskinan di Indonesia. Innovatio, 7 : 423-439.

Muhamad Muda, et al. 2006. Factors Influencing Individual Participation in Zakat Contribution: Exploratory Investigation. Kertas Kerja Pada Seminar for Islamic Banking and Finance Islamic University College of Malaysia.

Nurul Widyawati Islami Rahayu. 2014. Lembaga Amil Zakat, Politik Lokal dan Good Governance di Jember. STAIN Jember. 